\title{
Bycatch of Protected Megafauna in the Artisanal Coastal Fishery of Mayotte Island, Mozambique Channel
}

\author{
Pusineri, C. ${ }^{1}$ and Quillard, M. ${ }^{2}$ \\ ${ }^{I}$ Office National de la Chasse et de la Faune Sauvage, BP 6797670 COCONI, France; ${ }^{2}$ Observatoire des \\ Tortues Marines. Direction de l'Environnement et du Développement Durable, Conseil Général de Mayotte, \\ BP 101, 97600 Mamoudzou, France
}

Keywords: Bycatch, dugong, green turtle, hawksbill turtle, Mayotte island

\begin{abstract}
In Mayotte, in July 2007 interviews were conducted on 406 fishermen to assess the bycatch issue on marine megafauna. Seventy-eight fishermen said they caught at least one turtle so far that year, of which twelve were deliberate and 66 accidental. Of the turtle bycaught, 59 were released alive, six released dead and one eaten or sold. Nine fishermen caught at least one dugong during their life time, of which seven were accidental and two deliberate catches. All the animals were kept for meat consumption. Ten fishermen had caught one dolphin accidentally, with all animals released: two dead and eight alive. The handline was responsible for 48 turtle bycatches and three dolphin bycatches. The gillnet was responsible for 12 turtle bycatches, all the dugong catches and four dolphin bycatches. The estimation of bycatch mortality gave a range of 111 to 256 individuals year ${ }^{-1}$ for turtles, and very low rates $\left(<<1\right.$ ind.year $\left.^{-1}\right)$ for dolphins and dugong. These rates may be highly significant for small populations of hawksbill turtles and dugongs. Most of the fishermen knew the species were protected by law but did not seem to understand the issues behind this legislation. Management measures are proposed to deal with these important issues.
\end{abstract}

\section{INTRODUCTION}

While hunting used to be a major threat for marine megafauna, the last few decades have seen fisheries bycatch implicated in many population declines of sea turtles, marine mammals, seabirds and sharks (Lewison et al., 2004; Reeves et al., 2003). Due to their life-history strategies (long lifespan, late maturity, low reproductive rate) marine megafauna species are very sensitive to changes in sub-adult and adult survival. Hence, the bycatch of even a few individuals of these sensitive age classes can lead to a drastic population decline (Lewison et al., 2004). After the validation of several international conventions regarding fisheries practices (e.g. the UN Convention on the Law of the Sea of 1982, the FAO Code of Conduct for Responsible Fisheries) the bycatch issue is now one of the management priorities for fisheries and has led to several key workshops in the Western Indian Ocean (e.g.: FAO 2006; Kiszka \& Muir, 2006; Etienne et al., 2007). These meetings reached five common conclusions regarding bycatch issues in the WIO: first, that the coastal gillnet fishery poses a serious threat to turtles, dugongs and cetaceans; second, the highest priority is the dugong, which is severely threatened mainly from gillnetting and habitat disturbances; third, as infrastructure, facilities, human capacities and economic resources are limited in the region, data availability is very limited and legislation is still poor and often not enforced; fourth, the coastal population in the WIO is among the poorest in the world, hence, there is a need to consider the issue of "retained non-target catch" by coastal communities 
for protein through the development of alternatives, such as ecotourism; and fifth, that environmental awareness and knowledge is still poor and public involvement in conservation activities limited.

Mayotte $\left(12^{\circ} 50^{\prime} \mathrm{S}, 45^{\circ} 10^{\prime} \mathrm{E}\right)$ is situated in the northern Mozambique Channel between Madagascar and the East African coast (Figure 1). Although Mayotte belongs to the Comoros archipelago, this island has been a French Collectivity since 1976 and benefits from a relatively high level of development.

The fishery is still mainly coastal and artisanal in Mayotte. Most of the fishing vessels (73\%, Herfaut, 2006) are non-motorised outrigger canoes made from a single log. These traditional boats are essentially used for occasional fishing trips inside the lagoon with catches for home consumption. Small-motorised boats that enable fishing outside the lagoon in adjacent oceanic waters represent $27 \%$ of the fishing vessels.

Fishing has an important social role in Mayotte with 4,817 fishermen (3,516 sea fishermen and 1,301 fishermen who mainly fish on the intertidal area) and more than 4,341 families supported through this industry (INSEE, 2003; Huet et al., 2004). Fishing gears are traditional. Handlines are the most common fishing gear, used in $71 \%$ of the fishing trips (Herfaut, 2006). Nets, essentially small set gillnets and seine nets, and longlines are also used. Handlines and gill nets catch mainly small coral reef fishes while seine nets target small pelagic fish and longlines are employed for large pelagic fish (Fouquet, 2001). Fishery legislation is very strict in Mayotte: some fishing gears are forbidden inside the lagoon such as dynamite and spear guns. The use of nets is forbidden on coral reefs, seagrass beds and mangrove areas. Mesh size should not be larger than $6 \mathrm{~cm}$ and nets should be maximum $300 \mathrm{~m}$ long. Three small protected areas have been defined where fishing is even more restricted (e.g.: nets forbidden). The capture of some crustacean species is closed during their reproduction season. Sea turtles were partially protected in 1977 , and received full protection in 2000 . Since 1995 , marine mammals have been fully protected.

Mayotte Island is surrounded by one of the largest lagoon in the world $\left(1500 \mathrm{~km}^{2}\right)$ characterized by a high biodiversity. Four species of marine turtles occur in Mayotte waters (Observatory of Sea Turtles, OTM,pers. com.): the rare loggerheads
(Caretta caretta) and leatherbacks (Dermochelys coriacea) and the common and nesting greens (Chelonia mydas) and hawksbills (Eretmochelys imbricate). In 2007, the ratio of the number of nesting hawksbill to nesting green turtle was around 1:100 (OTM pers. com.) suggesting that the hawksbill population is quite small. The green turtle is herbivorous and mainly observed on seagrass beds while the hawksbill seems to consume essentially sponges and is observed most of the time on coral reefs. According to the IUCN, the hawksbill is critically endangered and the green turtle is endangered (Seminoff, 2004). Both species are classified in Appendix I of CITES (Convention of International Trade in Endangered Species). In the WIO, populations of these two species are believed to be severely depleted (FAO, 2004). An exception is Mayotte where the green turtle population is relatively healthy (Bourjea et al., 2007), however, evidence from numerous carcasses found on beaches as well as anecdotal reports from local fishermen suggest that fisheries bycatch and direct catch continue to pose significant threats.

More than 20 species of marine mammals are known to occur in the lagoon and adjacent waters (Kiszka et al., 2007a). The most common are the spinner dolphin (Stenella longirostris), the pantropical spotted dolphin (Stenella attenuata), the Indo-Pacific bottlenose dolphin (Tursiops truncatus), and the dugong (Dugong dugon). The dugong is an herbivorous animal that feeds on seagrass beds. It used to be common in Mayotte and was regularly caught for its meat (Kiszka et al., 2007b). It is now rarely observed in the lagoon and the last reported capture occurred in 2003. The population decline is thought to be due to overfishing but is still poorly understood. The dugong is classified as vulnerable by the IUCN and listed on Appendix I by CITES. The spinner dolphin and the pantropical spotted dolphin are observed along the outer slope of the barrier reef, while the Indo-Pacific bottlenose dolphin is observed mainly on the fringing reef. Bycatch has not been considered a major threat to cetaceans in Mayotte as neither stranded animals with fishing gear marks nor dolphin meat sale have ever been reported.

With the rapid economic development and population growth of the island, anthropogenic threats are increasing, such as chemical, biological 


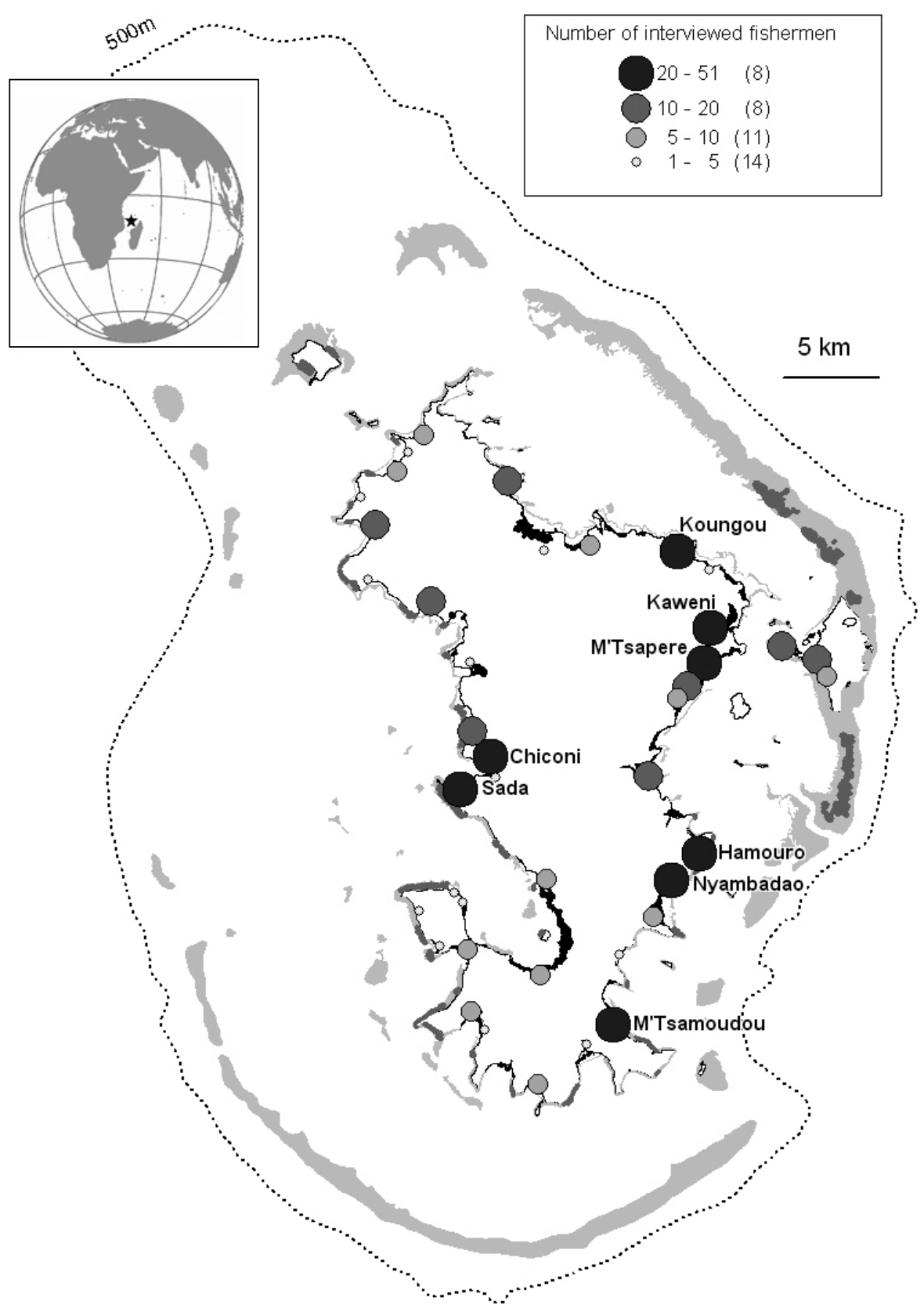

Fig. 1. Mayotte Island and the villages covered by the interview survey. Coral reefs are in light grey, seagrass beds in dark grey and mangroves in black. Legend numbers in parenthesis indicate the number of villages where the specified range of fishermen intervies were conducted

and acoustic pollution, coastal habitat degradation, overfishing, poaching and bycatch (Pusineri \& Kiszka, 2007). So far no quantitative data have been collected on bycatch and therefore an interview survey was conducted in 2007 with 406 fishermen. The main goals were to: 1) characterize turtle, dugong and dolphin bycatches: recording numbers, types of fishing gears and fishing locations; 2) determine the impact of these bycatches on megafauna species; 3) evaluate the fishermen's awareness and perception of the species status; and 4) make management recommendations. 


\section{MATERIALS AND METHODS}

\section{Data collection}

Data were collected in July 2007. Interviewers were selected with specific profiles: young local students in biology. Indeed, the fishermen of Mayotte fear repression and were thought to be more confident communicating with young people. Also, some fishermen do not speak French well enough, so interviewers were needed who fluently spoke the two local languages. Finally, it was reasoned that students in biology would have a good understanding of the purpose of the work and thus conduct the interview surveys properly. The four selected students attended a one-day training course before starting the interviews and a de-briefing took place daily during the first week. As the study was limited by time, the smallest fishing villages (number of fishing vessels $<10$; Herfaut, 2006) were not interviewed. In total, 41 villages of the 57 inventoried by the fishing office were selected. This should not bias the results as no significant difference in fishing methods between villages has been reported and the selected villages were distributed in a random fashion along the coast (see Figure 1). Interviews were conducted in the early morning at the landing sites when the fishermen returned from their night trips, and in the afternoons when fishermen returned from day trips. All the willing fishermen present on the landing sites were interviewed.

The questionnaire comprised 44 questions that were essentially multiple-choice questions (see Annex 1). This simple format was chosen because the interviewers were inexperienced. The questionnaire first focused on the fishermen themselves: age, fishing frequency, preferred fishing period, fishing gear and environment. Then questions were asked about dugong, sea turtles and dolphin catches: number of catches this year for turtles and number of catches during their lifetime for dugongs and dolphins; the characteristics of their last catch (date, deliberate or accidental, sex and species for the turtles, environment, fishing gear, location and use of the animal), then an assessment was made as to the sincerity of the fishermen being questioned. Then a last set of questions focused on species status awareness and perception by the fishermen. The answers to the few open questions were gathered into categories during data treatment. The fishing sites of Mayotte have been geographically referenced by Herfaut (2006). Hence, a map was added to the questionnaire and the fishermen were asked to locate precisely the capture sites on the map. The questionnaire was translated into the two local languages to make sure they would always be asked specifically in the same way. The questionnaire was accompanied by a flyer that presented the species and the laws that protect them. As many fishermen cannot read, the main information was summarized through drawings. The interviews were performed the following way: first, the group of interviewers presented their work to all the fishermen present on the landing site. Second, each student performed the interviews formally on a one-to-one basis with each willing fishermen. The interviewer presented the species with the help of the flyer and then asked the questions in the fishermen's preferred language. This lasted between 10 and 20 minutes. Third, the interviewer informed the respondent about the legislation on marine mammal and turtle protection.

\section{Estimate of turtle mortality}

A rough estimate of the turtles' bycatch mortality was computed with the following equations:

Equation 1: $\mathrm{N}_{\mathrm{bc} \text { min }}=\sum_{\mathrm{i}}\left(\mathrm{F}_{\mathrm{ci}} \times \mathrm{N}_{\mathrm{ci} \text { min }}\right) \times \mathrm{F}_{\mathrm{bc}} \times \mathrm{N}_{\mathrm{f}} \times \mathrm{F}_{\mathrm{d}}$ Equation 2: $\mathrm{N}_{\mathrm{bc} \max }=\Sigma_{\mathrm{i}}\left(\mathrm{F}_{\mathrm{ci}} \times \mathrm{N}_{\mathrm{ci} \max }\right) \times \mathrm{F}_{\mathrm{bc}} \times \mathrm{N}_{\mathrm{f}} \times \mathrm{F}_{\mathrm{d}}$ With:

$\mathrm{F}_{\mathrm{ci}}=$ Frequency of turtle catch (deliberate and accidental catches) per year

$\mathrm{N}_{\text {ci min }}=$ Minimum number of turtles catches per year. $\mathrm{N}_{\mathrm{c} 1 \text { min }}=1, \mathrm{~N}_{\mathrm{c} 2 \text { min }}=4, \mathrm{~N}_{\mathrm{c} 3 \text { min }}=11$

$\mathrm{N}_{\text {ci } \max }=$ Maximum number of turtles catches per year. $\mathrm{N}_{\mathrm{c} 1 \text { max }}=3, \mathrm{~N}_{\mathrm{c} 2 \max }=10, \mathrm{~N}_{\mathrm{c} 3 \text { min }}=15$

$\mathrm{F}_{\mathrm{bc}}=$ Frequency of accidental catch

$\mathrm{N}_{\mathrm{f}}=$ Number of fishermen. $\mathrm{N}_{\mathrm{f}}=3516$ (INSEE, 2003;

Huet et al., 2004)

$\mathrm{F}_{\mathrm{d}}=$ Mortality rate of turtle bycatch

We did not intend to quantify the impact of the deliberate catch from our results because this was not the purpose of the study. Furthermore, the deliberate catch is known to be mainly due to specialised poachers and not to fishermen (Mayotte 
Wildlife Agency pers. com.) so our data would have significantly underestimated the problem.

\section{RESULTS}

\section{Characteristics of the fishermen interviewed}

406 fishermen were interviewed around Mayotte from 41 fishing villages distributed along the coast (Figure 1). The fishermen interviewed were mainly between 18 and 55 years old $(81 \%, \mathrm{~N}=329$, Table 1). Most of the fishermen fish in open waters either outside or inside the lagoon (respectively $33 \%, \mathrm{~N}=135$, and $32 \%, \mathrm{~N}=129$ ). A relatively high proportion fish in the barrier reef vicinity $(22 \%$, $\mathrm{N}=90$ ). The others fish either on the fringing reefs or on seagrass beds. The preferred fishing gear was the handline ( $91 \%, \mathrm{~N}=369$ of the fishermen). Other gears included nets, longlines and spear guns.

\section{Sea turtle captures}

Most of the fishermen said they did not catch any turtle this year $(82 \%, \mathrm{~N}=328)$. Seventeen percent $(\mathrm{N}=68)$ said they caught between 1-3 turtles this year, one percent $(\mathrm{N}=5)$ said they caught between 4-10 and one percent $(\mathrm{N}=5)$ said they caught over ten turtles this year (Table 2). Most of the fishermen claimed their last turtle catch was accidental $(85 \%, \mathrm{~N}=66)$ and only $15 \%(\mathrm{~N}=12)$ said it was deliberate. Accidental and deliberate catches were very different. In bycatch cases, green turtles were four times more frequently caught than hawksbills. Only 12 fishermen were able to give the sex of their last catch and showed a balanced sex ratio (1/1). Bycatch occurred in all environments but were more frequent on seagrass beds $(42 \%, \mathrm{~N}=28)$ and open waters $(41 \%, \mathrm{~N}=27)$ (Table 2). The fishing gears most often responsible for the bycatch were the handline $(73 \%, \mathrm{~N}=48)$ followed by the net $(18 \%, \mathrm{~N}=12)$. The turtles were released alive in $89 \%(\mathrm{~N}=59)$ of the cases, released dead in $9 \%$ cases $(\mathrm{N}=6)$ and retained for meat consumption in $2 \%$ cases $(\mathrm{N}=1)$. Thirty-three percent of the turtles caught by nets died compared to $17 \%$ for animals caught with longlines and $4 \%$ for handline-caught turtles. Deliberate turtle catches were essentially
Table 1. Characteristics of the fishing activity of the interviewed fishermen. $N=$ number of individuals, $\% \mathrm{~N}$ $=$ percentage of number of individuals, $N A=$ no answer For preferred environments and preferred fishing gears, fishermen could give several answers

\begin{tabular}{|c|c|c|}
\hline Number of individuals & $\mathbf{N}$ & $\% \mathbf{N}$ \\
\hline \multicolumn{3}{|l|}{ Age } \\
\hline$<18$ & 2 & 0.5 \\
\hline 18-35 years old & 139 & 34.2 \\
\hline $35-55$ years old & 190 & 46.8 \\
\hline$>55$ years old & 73 & 18 \\
\hline No answer & 2 & 0.5 \\
\hline \multicolumn{3}{|l|}{ Fishing effort } \\
\hline Everyday & 58 & 14.3 \\
\hline Several times per week & 269 & 66.3 \\
\hline Once per week & 50 & 12.3 \\
\hline Less & 27 & 6.7 \\
\hline NA & 2 & 0.5 \\
\hline \multicolumn{3}{|l|}{ Preferred environments } \\
\hline Outside the lagoon & 135 & 33.3 \\
\hline Open water in the lagoon & 129 & 31.8 \\
\hline Barrier reef & 90 & 22.2 \\
\hline Fringing reef & 35 & 8.6 \\
\hline Seagrass & 31 & 7.6 \\
\hline Other & 4 & 1 \\
\hline \multicolumn{3}{|l|}{ Preferred fishing gears } \\
\hline Handline & 369 & 90.9 \\
\hline Net & 29 & 7.1 \\
\hline Longline & 21 & 5.2 \\
\hline Spear gun & 5 & 1.2 \\
\hline Other & 3 & 0.7 \\
\hline
\end{tabular}

performed by hand on female green turtles nesting on beaches. Only $10 \%$ of the fishermen did not appear sincere to the interviewers. The rough estimate of turtle bycatch mortality was computed from equations 1 and 2 with: $\mathrm{F}_{\mathrm{c} 1}=68 / 406, \mathrm{~F}_{\mathrm{c} 2}=$ $5 / 406, F_{c 2}=5 / 406, F_{b c}=66 / 78, F_{d}=7 / 66$. A range of 111 to 256 turtle deaths per year was obtained. With a bycatch ratio of 37 green turtles for 9 hawksbills, a range of 90 to 206 deaths of green turtles and 21 to 50 deaths of hawksbills per year were calculated.

\section{Dugong captures}

Of the 406 fishermen interviewed, nine caught a dugong in their net at least once in their life (Table 3 ). Most of the dugong captures reported occurred more than ten years previously (six of the nine 
Table 2. Characteristics of the turtle captures. $N=$ number of individuals, $\mathrm{NA}=$ no answer

\begin{tabular}{|c|c|c|}
\hline Number of individuals & $\mathbf{N}$ & $\% \mathbf{N}$ \\
\hline \multicolumn{3}{|c|}{ Number of turtle caught this year } \\
\hline 1 to 3 & 68 & 16.7 \\
\hline 4 to 10 & 5 & 1.2 \\
\hline More & 5 & 1.2 \\
\hline None & 328 & 80.8 \\
\hline \multicolumn{3}{|l|}{ Last capture type } \\
\hline Accidental & 66 & 84.6 \\
\hline \multirow[t]{3}{*}{ Deliberate } & 12 & 15.4 \\
\hline & $\begin{array}{l}\text { Accidental } \\
\text { catch }\end{array}$ & $\begin{array}{c}\text { Deliberate } \\
\text { catch }\end{array}$ \\
\hline & $\mathbf{N}$ & $\mathbf{N}$ \\
\hline \multicolumn{3}{|l|}{ Species of last capture } \\
\hline Green & 37 & 9 \\
\hline Hawksbill & 9 & 0 \\
\hline NA & 20 & 3 \\
\hline \multicolumn{3}{|l|}{ Sex of last capture } \\
\hline Female & 6 & 5 \\
\hline Male & 6 & 1 \\
\hline NA & 54 & 6 \\
\hline \multicolumn{3}{|c|}{ Environment of last capture } \\
\hline Seagrass & 28 & 2 \\
\hline Beach & 2 & 5 \\
\hline Open water & 27 & 1 \\
\hline Coral reefs & 7 & 2 \\
\hline NA & 2 & 2 \\
\hline \multicolumn{3}{|c|}{ Fishing gear of last capture } \\
\hline Net & 12 & 0 \\
\hline Harpoon & 0 & 1 \\
\hline Hand & 0 & 6 \\
\hline Handline & 48 & 3 \\
\hline Longline & 6 & 0 \\
\hline $\mathrm{NA}$ & 0 & 2 \\
\hline \multicolumn{3}{|c|}{ What did the last capture became } \\
\hline Realised alive & 59 & 0 \\
\hline Realised dead & 6 & 0 \\
\hline Eaten or sold & 1 & 10 \\
\hline NA & 0 & 2 \\
\hline
\end{tabular}

captures), and none had occurred in 2007. Seven fishermen said the dugong capture was accidental, while one answered it was deliberate. Five dugongs were found dead, four alive; yet all were retained for meat consumption and the police confiscated one carcass. From the catch locations it was noticed that the dugongs were caught all around the island, thought mainly on coastal seagrass beds.
Table 3. Characteristics of the dugong and the dolphin captures

\begin{tabular}{lll}
\hline Number of individuals $\quad$ Dugong & Dolphins
\end{tabular}

\section{Capture}

Caught at least one $\quad 9 \quad 10$

None

$397 \quad 387$

When

$>10$ years ago

6-10 years ago

$1-5$ years ago

This year

Capture type

Accidental

Deliberate

NA

$\begin{array}{ll}2 & 3 \\ 1 & 5 \\ 0 & 1\end{array}$

Fishing gear

Net

Handline

Longline

Animal use

Released dead

Released alive

$\begin{array}{ll}7 & 10\end{array}$

10

10

Found alive but retained for meat consumption

Found dead but retained for meat consumption

Found dead and confiscated by the police

$\begin{array}{ll}9 & 4 \\ 0 & 3 \\ 0 & 3\end{array}$

\section{Dolphin captures}

Of the 406 interviewed fishermen, ten reported to have caught a dolphin at least once (Table 3). All the catches were said to be accidental. Four dolphins were caught in a net, three on handlines and three on longlines. Eight animals were released alive and two, bycaught with a net, were found dead, but disposed of. Three captures occurred on the fringing reef, the preferred habitat of bottlenose dolphins, three outside the barrier reef and two in the barrier reef passes, the preferred habitat of the spinner and spotted dolphins.

\section{Species protection awareness}

Most of the fishermen said there is an interest in protecting the dugong $(92 \%, \mathrm{~N}=372)$, the turtles $(96 \%, N=391)$ and the dolphins $(92 \%, 375)$. The main reasons given were gathered into the following 
categories: "in order to preserve the environment/the biodiversity" (turtles: 35\%; dugong: 32\%; dolphins: $18 \%$ ), "it is a rare animal" (dugong: $14 \%$ ), "for the next generations" (dugong: 13\%; turtles: 6\%), "it is not edible" (dolphins: 24\%; turtles: 13\%; dugong: $8 \%$ ), "for the tourism" (dolphins: $24 \%$; turtles: 16\%; dugong: $8 \%$ ), "it is human-like" (dugong: $4 \%$ ), it is "protected by law" (turtles: 6\%).

The majority of fishermen knew dugongs were threatened with extinction $(71 \%, \mathrm{~N}=287)$ but less than half of them were aware that turtles were also threatened (45\%, $\mathrm{N}=183)$. Most of the fishermen were aware that dugongs $(85 \%, \mathrm{~N}=343)$, turtles (92\%, $\mathrm{N}=372)$ and dolphins $(88 \%, \mathrm{~N}=356)$ were protected by law. Fifty-four percent $(\mathrm{N}=218)$ of the fishermen thought that the turtle population was increasing and $80 \%(\mathrm{~N}=324)$ thought dolphin numbers were increasing. Among the fishermen that had an opinion on the period of the dugong population decline, most of them answered during the 70's $(12 \%, \mathrm{~N}=50)$, the 80 's $(14 \%, \mathrm{~N}=58)$ and the 90 's $(9 \%, \mathrm{~N}=37)$.

\section{DISCUSSION}

\section{Major findings}

The rough estimate of turtle mortality due to the bycatch in the traditional fishery gave an order of magnitude of 90 to 206 deaths of green turtles and a range of 21 to 50 deaths of hawksbills per year. Bycatch rates were low $\left(<<1\right.$ ind.year $\left.{ }^{-1}\right)$ for dolphins and dugongs. The second major finding of the study is that both handlines and nets are major threats to Mayotte marine megafauna. Indeed, handlines, the most common fishing gear in the Mayotte traditional fishery (prefered fishing gear for $91 \%$ of interviewed fishermen), are responsible for most of the turtle catch $(73 \%)$. Although the use of nets is not common in the lagoon (prefered fishing gear of $7 \%$ of interviewed fishermen), this fishing gear was responsible for quite a high proportion of the turtle catch (18\%). Furthermore, the probability of a turtle dying once caught was greater in nets than in any other fishing gear (33\%). The nine dugong catches involved nets. Dolphins were caught both with nets and lines but only nets resulted in the death of some animals (two of the ten bycatches).
A third major finding is that most of the fishermen knew the species were protected but did not seem to understand the issues behind this legislation.

\section{Limits of the study}

The sample size was quite important as almost $10 \%$ of the fishing population of Mayotte was interviewed. However, only willing fishermen were interviewed which may lead to an underestimation of the number of catches, especially the deliberate catch.

We can be confident on the data collected about dolphins as neither the incidental nor the deliberate catches have ever been reported as major threats to the species in Mayotte and dolphin meat is not consumed locally. Conversely, catches of turtles and dugongs have been suspected to be a major problem for several decades. Indeed, some individuals have been reported by the local wildlife agency of poaching or selling meat of turtle and dugong. Similarly, there have been calls for better law enforcement of net use restrictions (e.g. nets forbidden on coral reefs, seagrass beds and mangrove areas, mesh size $<6 \mathrm{~cm}$ ). Hence, fishermen may not have been honest answering questions linked to these sensitive points. As a result, there may be an underestimation of the number of turtles and dugongs caught, especially the number of the deliberate catch, as well as the number of animals kept for consumption and the number of animals caught in nets (in parallel with an overestimation of handline bycatch). However, only a low proportion of the fishermen did not appear to answer the questions honestly (4\% for dugong, $10 \%$ for turtles) and the students did not feel the fishermen were suspicious of them. Furthermore, the fishermen answered surprisingly honestly to some sensitive questions such as the fate of the dugong (all the animals were said to be kept for consumption), so there is no particular reason to think they openly lied to the other sensitive queries. Furthermore, the local wildlife agency supported the results, observing that fishermen are rarely involved in turtle poaching or meat sales and that no dugong catches have been reported since 2003 . Hence, if there is some bias in the results, we can still be confident in their orders of magnitude and trends. 
The turtle bycatch estimate was made from simplistic equations that did not take into account variability such as differences among fishermen with respect to frequency of fishing effort, type of fishing or fishing location. However, given the data collection method and the low number of catches reported, we thought it would not be reasonable to build a more sophisticated model. We then considered that our sampling provided a good representation of the population of fishermen and instead used a simple model. Given this, the estimate should be considered as an order of magnitude and not a precise representation of bycatch.

As the interviews were performed by inexperienced students, we chose a very simple and formal interview format with a questionnaire made of multiple-choices questions. Consequently, very precise data was collected but important information that could have been reported during more informal exchanges may have been missed.

\section{Catch characterization}

As we have seen before, a major finding is that both handlines and nets are major threats to Mayotte marine megafauna. Another characteristic of the catches is that they occurred all around the island but that a higher catch rate was observed in the species' preferred habitats: the dugong catch occurred mainly on seagrass beds, where the species is observed most of the time foraging (Kiszka, 2005). The dolphin catch occurred either in coastal areas, the typical habitat of the bottlenose dolphin or near the barrier reef where the Stenella genus is mainly observed (Gross, 2006). The turtle catch occurred mainly on seagrass beds, the foraging and preferred habitat of the green turtle in Mayotte lagoon (Ross et al., 2005). However, there were a surprising number of turtle catches in open waters. Sea turtles may be found in open waters during mating, when travelling between resting (coral reef slope) and feeding sites, namely seagrass beds (Taquet et al., 2006), or during movements from feeding to nesting sites. Alternatively, it may simply be due to the greater fishing effort in these waters as these are the most exploited waters in the Mayotte fishery.

\section{Impact on the populations}

The rough estimate of turtle mortality due to the bycatch in the traditional fishery provide an order of magnitude of 90 to 206 deaths of green turtles and a range of 21 to 50 deaths of hawksbills per year. The abundance of foraging turtles has been assessed in Ngouja seagrass bed, the green turtles' main grazing site, and on 12 reef flats around the main island (Ross et al., 2005). A density of 1,200 to 1,400 individuals' $\mathrm{km}^{-2}$ was found in Ngouja and a density of 13 to 297 individuals' $\mathrm{km}^{-2}$ was found for the other sites on reef flats. The seagrass bed surface in Mayotte is 760 ha (Loricourt, 2006). These results are not detailed enough to compute the total number of grazing green turtles in the lagoon but we may estimate that the population is of several thousand individuals. Hence, the actual catch rate seems quite important for the green turtle and added to the other threats (in particular habitat destruction and poaching) may be a problem for the species in Mayotte. As for the hawksbill turtles, given the small population, the catch rate is very high and may be significant.

The two turtle species are well differentiated in the local culture and are given different names: the hawksbill is called "nyamba mali" (the rich turtle) while the green turtle is simply called "nyamba" (turtle). Hence, we can be quite confident in the identifications given by the fishermen. Given this, we may wonder why a higher catch rate was found for the hawksbill than for the green turtle. The interviews showed that fishing is more frequent on coral reefs than seagrass beds. The fact that hawksbill is more abundant on coral reefs, while the green turtle is mainly observed on seagrass beds, may partly explain the difference, but this point needs further study.

The dugong bycatch rate seems to be very low $(<<1 /$ year) but all catches are retained for meat consumption and the population is known to be very small. Therefore, each single dugong catch is significant for the population.

Only two dolphin deaths due to the bycatch in more than 10 years have been reported, which is likely to be of minor impact on the delphinids' population. 


\section{Comparison with other countries of the WIO}

The bycatch characteristics in Mayotte are quite different from the situation in most of the Western Indian Ocean countries. First, in general in the WIO countries, the main threat to sea turtles in artisanal fisheries is nets, particularly gillnets (FAO, 2006) while in Mayotte most of turtles catches seem to be due to handlines. Second, high rates of dolphin catches have been observed mainly due to gillnets in some areas. For example, in Anakao in Madagascar, 707 dolphin catches were reported between 2000 and 2007 (Razafindrakoto et al., 2006). Similarly, in Zanzibar, 96 dolphin catches were reported between 1995 and 1996 (Amir et al., 2002). Third, the dugong bycatch is slightly more numerous in some countries of the region. In Moheli, a total of 156 fishermen who had observed dugongs were interviewed in 2006, resulting in a total of 392 dugong sightings, $65 \%$ of which were alive, and 35\% dead (Davis \& Poonian, 2006). In Tanzania, at least seven dugongs were recorded drowned between 2004 and 2006 around Mafia Island (Muir \& St John, 2006).

The lower megafauna catch in the Mayotte traditional fishery is the result of several factors, including net use restriction, cultural differences with neighbouring countries, the reduced state of the dugong population and higher law enforcement levels. Indeed, because of net use restriction (forbidden on seagrass, coral reefs and mangroves and maximum mesh size of $6 \mathrm{~cm}$ ), this fishing gear is not only less threatening for large animals but also not common in Mayotte. For dolphins, consumption of dolphin meat is not a common practice in the local culture. Concerning the dugong, the population is so small in Mayotte that catches are rare. Lastly, the high economic development of Mayotte, allows more investment in law enforcement and education.

\section{Environmental awareness}

Most of the fishermen were aware that laws protect the sea turtles, the dugongs and the dolphins and said that there is an interest in protecting these species. However, when the fishermen were asked why it was important for them to protect these species, many of them gave the answer "for the environment" without more detail. Furthermore, most of the fishermen did not know that turtles are in danger of extinction and most of them even thought their populations as well as that of dolphins were increasing. Some fishermen also said the dugong was just a myth and did not exist. Finally, a small proportion of fishermen were still unaware of the legislation. These results highlight that there is a lack of communication about environmental awareness towards the local population and most importantly, that the quality of the communication is not satisfactory. Indeed, the fact that most fishermen were not aware of the issues behind these legislations may decrease their willingness to comply with the law.

\section{Management orientations}

Poaching, incidental catch kept for consumption, bycatch with nets in areas where this gear is forbidden and the lack of awareness about legislation, highlight the urgent need for an educational programme toward the population through more communication and community involvement. Strengthening law enforcement through more field police patrolling should also be considered. Since these species are highly migratory, the development of collaborative programs with neighbouring countries is also important especially for the most threatened species, the dugong. Some studies must be urgently considered such as determining population abundance, and the refinement of bycatch impacts from direct ground observation on landing and fishing sites. The interview process has proved to be very cost-effective and we suggest repeating it every two to four years to monitor fisheries' bycatch. Other mitigation measures could be considered, such as modifying fishing gears or prohibiting nets from the lagoon while helping fishermen to develop alternative fishing methods and economic activities.

Acknowledgments - The authors would like to thank the Collectivité Départementale de Mayotte and the Office National de la Chasse et de la Faune Sauvage for funding this study. We are grateful to Hamada 
Omar, Nawalidine Soulaimana, Oiziri Daniel, Randrianatoanina Stephanie as well as to the technicians of the OTM (Soula Assani and Samion Soumaïla) and the Brigade Nature de Mayotte for their involvement and support. We would also like to thank Stephane Ciccione, Jérôme Bourjea, Catharine Muir, Richard Jeffery and the reviewers for their useful comments and corrections.

\section{REFERENCES}

Amir, O.A., Berggren, P. \& Jiddawi, N.S. (2002) The Incidental Catch of Dolphins in Gillnet Fisheries in Zanzibar, Tanzania. Western Indian Ocean J. Mar.Sci., 1: 155-162.

Bourjea, J., Frappier, J., Quillard, M., Ciccione, S., Roos, D., Hughes, G. \& Grizel, H. (2007) Mayotte Island: another important green turtle nesting site in the southwest Indian Ocean. Endang. Species Res., 3, 273-282.

Davis, P.Z.R., Poonian, C.N.S. (2006) Accidental capture of the dugong (Dugong dugon) in gillnets, Mohéli, Union of the Comoros. In Kiszka, J. \& Muir, C. (Eds). Incidental catch of non-targeted marine species in the Western Idian Ocean: problems and mitigation measures. Workshop proceeding. 13-15 th November 2006, Mayotte, France. Pp. 58-61.

Etienne, D., Vely, M. \& Giroux, F. (2007) Atelier régional d'étude et de conservation des cétacés des pays de la COI. COI, Sainte Marie, Madagascar. $61 \mathrm{pp}$.

FAO (2004) Expert Consultation on Interactions between Sea Turtles and Fisheries within an Ecosystem Context - Rome, 9-12 March 2004. FAO Fisheries Report 738/Suppl.: 85-134.

FAO (2006) Workshop on Assessing the Relative Importance of Sea Turtle Mortality Due to Fisheries. FAO, Zanzibar, United Republic of Tanzania. 64pp.

Fouquet, P. (2001) Situation de la pêche artisanale à Mayotte en l'an 2000, Analyse statistique du système de suivi de l'activité halieutique (janvier 1997 - juin 2000). Master Thesis, University of Caen. 63pp.

Gross, A. (2006) Ségrégation écologique des delphinidés tropicaux: utilisation comparée des habitats et des ressources. Master Thesis, Université de La Rochelle. 39pp.

Herfaut, J. (2006) Suivi statistique de la pêche artisanale mahoraise: effort de pêche, capture et CPUE en 2005. DAF, CDM, Mamoudzou, Mayotte. 24pp.
Huet, S., Abalkini, A., Herfaut, J. (2004). Agreste Mayotte- $n^{\circ} 1$ - mai 2004. DAF, Mayotte, France.4pp.

INSEE (2003). Tableau Economique de Mayotte 2003/2004. Institut Nationale de la Statistique et des Etudes Economiques (INSEE) de la Réunion antenne de Mayotte, Mayotte, France. 136 pp.

Kiszka, J. (2005) Statut et conservation du dugong (Dugong dugon, Muller 1776) dans le lagon de Mayotte (Comores, Canal de Mozambique). Arvicola, 16: 49-54.

Kiszka, J. \& Muir, C. (2006) Incidental catch of non-targeted marine species in the Western Idian Ocean: problems and mitigation measures. WIOMSA, ULR, Sea Sense, Mayotte, France. $27 \mathrm{pp}$.

Kiszka, J., Ersts, P. \& Ridoux, V. (2007a) Cetacean diversity around the Mozambique Channel island of Mayotte (Comoros archipelago). J. Cetacean Res. Manage., 9: 105-109.

Kiszka, J., Muir, C. \& Jamon, A. (2007b) Status of a Marginal Dugong (Dugong Dugon) Population in the Lagoon of Mayotte (Mozambique Channel), in the Western Indian Ocean. Western Indian Ocean J. Mar. Sci., 6: 111-116.

Lewison, R.L., Crowder, L.B., Read, A.J. \& Freeman, S.A. (2004) Understanding impacts of fisheries bycatch on marine megafauna. TRENDS Ecol. Evol., 19: 598-604.

Loricourt,A. (2006) Etude des herbiers à phanérogames marines à Mayotte. Master Thesis, Université de Pau et des Pays de l'Adour. 62pp.

Muir, C., \& St John, F. (2006) Sea Sense Annual Report. Sea Sense, Tanzania. 2pp.

Pusineri, C. \& Kiszka, J. (2007) Defining a conservation action plan for the marine mammal population of the fast developing island of Mayotte, southwest Indian Ocean. In 17th Conference on the Biology of marine mammals. SMM, Cape Town, South Africa.

Razafindrakoto, Y., Andrianarivelo, N., Cerchio, S., Rosebaum, H.C., Rasoamananto, I. (2006) Assessing the extent of cetacean bycatch I the artisanal gillnet fisheries and direct captures in the south-western region of Madagascar. Pp: 45-52. In Kiszka, J. \& Muir, C. (Eds). Incidental catch of non-targeted marine species in the Western Idian Ocean: problems and mitigation measures. Workshop proceeding. 13-15 $5^{\text {th }}$ November 2006, Mayotte, France. 11pp.

Reeves, R.R.,Smith, B.D.,Crespo,E.A.\& Notarbartolo di Sciara, G. (2003) Dolphins, Whales and Porpoises - 2002-2010 Conservation Action Plan for the World's Cetaceans. IUCN, Gland, Switzerland and Cambridge, UK. 139pp. 
Ross, D., Pelletier, D., Ciccione, S., Taquet, M. \& Hughes, G. (2005) Aerial and snorkelling census techniques for estimating green turtle abundance on foraging areas: A pilot study in Mayotte Island (Indian Ocean). Aquat. Living Ressour., 18, 193-198.

Seminoff, J.A. (2004). 2004 Global Status Assessment - Green turtle (Chelonia mydas). Marine Turtle Specialist Group. The World Conservation Union (IUCN): Special Survival Commission; Red List Programme. 71pp.
Taquet, C., Taquet, M., Dempster, T., Soria, M., Ciccione, S., Roos, D. \& Dagorn, L. (2006) Foraging of the green sea turtle Chelonia mydas on seagrass beds at Mayotte Island (Indian Ocean), determined by acoustic transmitters. Mar. Ecol.Prog. Ser., 306, 295-302. 
Annex 1. Bycatch questionnaire used for the present study

\begin{tabular}{|c|c|c|c|c|c|}
\hline \multicolumn{6}{|c|}{ GENERAL } \\
\hline Name of interviewer: & \multirow{2}{*}{\multicolumn{2}{|c|}{$\begin{array}{l}\text { Fishing frequency: } \\
\square \text { Everyday } \\
\square \text { Several times per week } \\
\square \text { Once per week } \\
\square \text { Less } \\
\end{array}$}} & \multirow{2}{*}{\multicolumn{2}{|c|}{$\begin{array}{l}\text { Preferred fishing environment: } \\
\square \text { Seagrass beds } \\
\square \text { Fringing reef } \\
\square \text { Barrier reef }\end{array}$}} & $\begin{array}{l}\square \text { Open water outside the lagoon } \\
\square \text { open waters inside the lagoon }\end{array}$ \\
\hline Date: & & & & & $\square$ Other : .............. \\
\hline Village of interview: & $\begin{array}{l}\text { Main fishing gear: } \\
\square \text { Longline } \\
\square \text { Handline }\end{array}$ & $\begin{array}{l}\square \text { Net } \\
\square \text { Spear gun } \\
\square \text { Other:.............. }\end{array}$ & Age of interviewee: & $\begin{array}{l}\square 18 \mathrm{t} \\
\square>55\end{array}$ & $\begin{array}{l}\text { ars old } \square 36 \text { to } 55 \text { years old } \\
\text { ld }\end{array}$ \\
\hline
\end{tabular}

- Have you ever caught dugongs? If yes: 1 dugong $\square$

yes $\square$

DUGONG

no $\square$

- Characteristics of your last dugong catch

\begin{tabular}{|c|c|c|c|c|}
\hline when & $\square$ this year & $1-5$ years ago & $\square 6-10$ years ago & $\square>10$ years ago \\
\hline \multicolumn{5}{|c|}{ which place (show on map) $\ldots \ldots \ldots \ldots \ldots$} \\
\hline catch type & $\square$ bycatch & $\square$ deliberate & $\square$ don't know & \\
\hline fishing tool & $\square$ net & harpoon & $\square$ other : ............... & \\
\hline if the dugong was dead & $\square$ you let in the water & $\square$ you took it to eat it & $\square$ you took it to sale the meat & $\square$ other: ... \\
\hline if the dugong was alive & $\square$ you let it go & $\square$ you took it to eat it & $\square$ you took it to sale the meat & $\square$ other: ............. \\
\hline
\end{tabular}

- When do you think the dugong population started to decline rapidly:

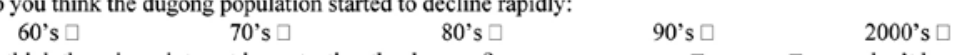

- Dou you think there is an interest in protecting the dugong ? $\quad$ yes $\square \quad$ no $\square \quad$ don't know

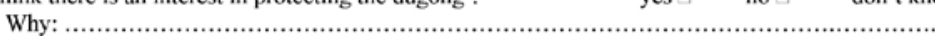

- Do you know that the dugong in Mayotte is: in the process of extinction: $\quad$ yes $\square \quad$ no $\square$

- Does the fishermen seem sincere ? yes $\square \quad \begin{gathered}\text { protected by law (kill it, eat it, hurt it is forbidder } \\ \text { no }\end{gathered} \quad \begin{gathered}\text { don't know } \square \\ \text { n }\end{gathered}$

yes $\square$

no $\square$

\section{SEA TURTLES}

- How many turtles did you catch this year: none $\square \quad 1$ to $3 \square \quad 4$ to $10 \square$ More $\square$

- Characteristics of the last turtle catch

\begin{tabular}{|c|c|c|c|c|}
\hline species & $\square$ green turtle & $\square$ Hawksbill Turtle & $\square$ don't know & \\
\hline $\operatorname{sex}$ & $\square$ male & $\square$ Female & $\square$ don't know & \\
\hline if the turtle was dead & $\square$ you let in the water & $\square$ you took it to eat it & $\square$ you took it to sale the meat & $\square$ other : ................ \\
\hline if the turtle was alive & $\square$ you let it go & $\square$ you took it to eat it & $\square$ you took it to sale the meat & $\square$ other: ............. \\
\hline catch type & $\square$ bycatch & $\square$ deliberate & $\square$ don't know & \\
\hline fishing tool & $\square$ net & $\square$ line & $\square$ other : .............. & \\
\hline which environment & $\square$ seagrass bed & $\square$ open waters & $\square$ coral reef slope & $\square$ don't know \\
\hline
\end{tabular}

- Do you think there is an interest in protecting the turtle ? $\quad$ yes $\square \quad$ no $\square$ don't know $\square$ Why: . - Do you know that the turtles observed in Mayotte are: in the process of extinction: $\quad$ yes $\square \quad$ no $\square$
protected by law (kill it, eat it, hurt it is forbidden): yes $\square$

no $\square$

- Compared to 10-20 years ago, do you think the turtles are: more numerous $\square$

- Does the fishermen seem sincere? yes $\square$ no $\square$ don't know

less numerous $\square$

as numerous $\square$

\section{DOLPHINS}

- Have you ever caught dolphins?
If yes: 1 dolphin $\square \quad$ between 2 and 5

no $\square$

between 6 and 10

More $\square$

- Characteristics of the last dolphin catch

\begin{tabular}{|c|c|c|c|c|}
\hline catch type & $\square$ bycatch & $\square$ deliberate & $\square$ don't know & \\
\hline when & $\square$ this year & $\square 1-5$ years ago & 6-10 years ago & $\square>10$ years ago \\
\hline period of the day & $\square$ daylight & $\square$ night & & \\
\hline which place (show on map) & $\ldots$ & 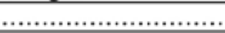 & $\ldots \ldots \ldots$ & \\
\hline fishing tool & $\square$ net & $\square$ line & $\square$ other : ............. & \\
\hline if the dolphin was dead & $\square$ you let in the water & $\square$ you took it to eat it & $\square$ you took it to sale the meat & $\square$ other : ............. \\
\hline if the dolphin was alive & $\square$ you let it go & $\square$ you took it to eat it & $\square$ you took it to sale the meat & $\square$ other: ....... \\
\hline
\end{tabular}

- Do you think there is an interest in protecting the dolphins ? yes $\square \quad$ no $\square \quad$ don't know $\square$

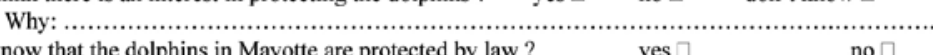

- Do you know that the dolphins in Mayotte are protected by law ? no $\square$

- Compared to 20-30 years ago, do you think the dolphins are: more numerous than $\square$ less numerous $\square$

as numerous 